\author{
Нікішина О.В. \\ кандидат економічних наук, докторант \\ відділ ринкових механізмів та структур \\ Інститут проблем ринку та економіко-екологічних досліджень НАН України \\ Французький бульвар, 29, м. Одеса, Україна, 65044 \\ E-mail: ksenkych@gmail.com
}

\title{
КООПЕРАТИВНІ ОБ'ЄДНАННЯ В РОЗВИТКУ ІНФРАСТРУКТУРИ ЗЕРНОВОГО РИНКУ УКРАЇНИ
}

Визначено передумови створення системи зернових кооперативів, головні причини їх нерозвиненості в Україні. Обґрунтовано очікувані соціально-економічні ефекти, завдання і організаційна структура зернового обслуговуючого кооперативу, центральною ланкою якого є кооперативний елеватор. Доведено доцільність створення та державної підтримки кооперативів як стратегічного напряму розвитку інфрраструктури зернового ринку шляхом розрахунку ефективності реалізації зерна за кооперативним і посередницьким збутовим каналом.

Ключові слова: зерновий кооператив, інфраструктура ринку, збутові канали, кооперативний елеватор, ефективність реалізації зерна.

Постановка проблеми та її зв'язок $з$ важливими науковими та практичними завданнями. Ефективність функціонування стратегічного зернового ринку, що виступає гарантом продовольчої безпеки України, залежить від ефективності багатоканальної збутової системи. Впливаючи на економічні інтереси суб'єктів виробництва і зберігання зерна, трейдерів, переробних підприємств і держави, дана система в значній мірі визначає ефективність інфраструктури інтегрованого зернового ринку, рентабельність діяльності його суб'єктів, напрями і заходи державного цілеспрямованого регулювання. Збутова система $є$ багатофункціональною, узгоджуючи попит і пропозицію зернових культур із різними параметрами якості, визначаючи їх ціну, строки та канал реалізації, інформуючи всіх учасників каналу товароруху.

Ми солідарні $з$ науковою позицією А.І. Алтухова в тому, що ступінь ефективності функціонування інфраструктури відображає ступінь зрілості зернового ринку [1, с. 398-406]. На думку В.О. Солопова, напрям дії базового закону попиту та пропозиції у значній мірі залежить від стану ринкової інфраструктури, яка є безпосереднім носієм ринкових сигналів між секторами інтегрованого ринку. При цьому ступінь викривлення і швидкість проходження цих сигналів впливає на кон'юнктуру ринку, сприяючи згладжуванню або посиленню цінових коливань [2, c. 223]. Сьогодні надзвичайної актуальності набула проблема формування в ринковій системі інституцій попиту, а не лише пропозиції. Відтак, створення та функціонування системи зернових кооперативів в Україні є одним зі стратегічних напрямів розвитку інфраструктури інтегрованого зернового ринку, важливою інституцією попиту, покликаною збалансувати економічні інтереси малих зерновиробників, держави, великих трейдерських і монопольних структур.

Аналіз останніх публікацій 3 проблеми. Концептуальні основи функціонування багатоканальних систем збуту аграрної продукції, в т.ч. і зерна, знайшли відображення в працях А. Алтухова [1], Т. Амблера [3], Д. Джобберга [4], М. Дем'яненка [5], С. Кваші [6], П. Саблука [7], В. Солопова [2], Л. Франченко [8], М. Хорунжого [9], В. Шебаніна [10] та інших учених. Водночас недостатньо вивченими залишаються питання ідентифікації проблем розвитку зернових кооперативів в Україні та шляхів їх розв'язання, оцінки ефективності кооперативного збутового каналу порівняно $з$ іншими каналами товароруху зерна, що обумовило мету і завдання даної статті.

Формулювання цілей дослідження. Мета статті - обгрунтування доцільності створення системи обслуговуючих кооперативів як стратегічного напряму розвитку інфраструктури зернового ринку окреслила низку завдань:

- аналіз передумов створення кооперативних об'єднань в Україні;

- обгрунтування очікуваних ефектів, завдань і організаційної структури регіонального зернового обслуговуючого кооперативу; 
- оцінка ефективності реалізації зерна за кооперативним і посередницьким збутовим каналом на внутрішньому та зовнішньому ринках.

Виклад основних результатів та їх обгрунтування. Головними передумовами створення системи зернових кооперативів в Україні є такі: (1) низька частка первинних агровиробників у кінцевій ціні продукції (30-40 \% в Україні порівняно з 50-70\% в ЄС і США [7, с. 5]); (2) цінова залежність малих і середніх зерновиробників від монопсонічних цін трейдерів і тарифів регіональних приватних елеваторів; (3) обмеженість доступу малих сільськогосподарських підприємств (далі - СГП), зокрема, фермерських господарств до участі в державних програмах щодо розвитку зернового ринку; (4) відсутність права доступу особистих господарств населення (фізичних осіб) до участі в державних програмах, до отримання будь-яких видів і форм державної підтри- мки зернового господарства; (5) низька конкурентоспроможність малих СГП в умовах агроглобалізації тощо.

Проявом нерозвиненості інфраструктури зернового ринку України є домінування у структурі збутових каналів непрозорих «інших каналів», зростання їх питомої ваги з 3,2 \% в 1990 р. до 86,8 \% в 2013 р. за рахунок зменшення частки зернопереробного напряму реалізації зерна (таблиця 1), нерозвиненість державного збутового каналу, низька частка (2-3\%) реалізації зерна через товарні біржі, інформаційна непрозорість ринку. За статистичними даними, у 2013 р. за посередницьким «іншим каналом» СГП реалізували 33,2 млн. т зернових культур, що склало 52,7 \% від загального валового збору. Частки таких каналів реалізації зерна, як «на ринку» та «населенню в рахунок оплати праці» $\epsilon$ незначними i складають $3,4 \%$ і 5,8 \% відповідно.

Таблиця 1

Структура реалізації зернових культур СГП в Україні, \%*

\begin{tabular}{|c|c|c|c|c|c|c|c|c|c|c|}
\hline \multirow{2}{*}{ Канали реалізації } & \multicolumn{10}{|c|}{ Роки } \\
\hline & 1990 & 1995 & 2000 & 2005 & 2008 & 2009 & 2010 & 2011 & 2012 & 2013 \\
\hline 1. Переробним підприємствам & 80,4 & 37,5 & 4,0 & 5,2 & 4,4 & 3,9 & 3,4 & 3,6 & 3,7 & 4,0 \\
\hline 2.На ринку & 3,2 & 19,2 & 34,8 & 10,0 & 7,9 & 6,6 & 7,1 & 4,9 & 3,7 & 3,4 \\
\hline $\begin{array}{l}\text { 3. Населенню в рахунок оплати } \\
\text { праці та пайовикам в рахунок } \\
\text { орендної плати }\end{array}$ & 13,2 & 30,3 & 34,7 & 15,2 & 10,7 & 8,4 & 10,5 & 8,8 & 6,3 & 5,8 \\
\hline 4. За іншими каналами & 3,2 & 13,0 & 26,5 & 69,6 & 77,0 & 81,1 & 79,0 & 82,7 & 86,3 & 86,8 \\
\hline $\begin{array}{l}\text { 5. Усього реалізовано зерна СГП, } \\
\text { млн. тонн }\end{array}$ & 18,5 & 13,1 & 10,7 & 19,5 & 24,8 & 31,7 & 23,7 & 28,6 & 33,7 & 38,3 \\
\hline у\% до валового збору & 37,3 & 42,0 & 53,8 & 67,6 & 46,5 & 68,8 & 60,3 & 50,4 & 72,8 & 60,7 \\
\hline
\end{tabular}

*Складено за даними Державної служби статистики України $[11,12]$

Частину зерна, придбаного в СГП, трейдери реалізують на внутрішньому ринку переробним підприємствам; у 2013 р. його обсяги склали 4,5 млн. т (таблиця 2). Існування посередницької ланки у збутовій системі призводить до зростання собівартості продуктів зернопереробки, скорочення прибутковості виробників соціально значимих сортів борошна за фіксованого рівня їх рентабельності. Водночас слід відзначити незначні позитивні зміни у структурі каналів товароруху. Так, частка зерна, що надходить на переробку від безпосередніх виробників - СГП і господарств населення - зросла $340 \%$ у 2002 р. до $55,5 \%$ у 2013 р. і з 2,9 \% до 4,5 \% відповідно за рахунок скорочення обсягів надходжень від інших господарських структур на 17,2 \% (див. табл. 2). 
Таблиця 2

Динаміка та структура надходжень зернових культур на переробні підприсмства України, млн. т*

\begin{tabular}{|c|c|c|c|c|c|c|c|c|c|}
\hline \multirow{2}{*}{ Канали реалізації } & \multicolumn{8}{|c|}{ Роки } & \multirow{2}{*}{$\begin{array}{l}2013 \text { p. } \\
\text { у \% до } \\
2002 \text { p. }\end{array}$} \\
\hline & 2002 & 2005 & 2008 & 2009 & 2010 & 2011 & 2012 & 2013 & \\
\hline Всього, у т.ч. від: & 7,78 & 8,62 & 10,63 & 10,26 & 8,91 & 10,70 & 10,27 & 10,79 & 138,6 \\
\hline 1. СГП & 3,11 & 3,31 & 4,83 & 5,06 & 4,40 & 5,79 & 5,37 & 6,25 & y 2 p. \\
\hline 2. Господарств населення & 0,22 & 0,07 & 0,04 & 0,07 & 0,07 & 0,02 & 0,36 & 0,51 & $\mathrm{y} 2,3 \mathrm{p}$. \\
\hline $\begin{array}{l}\text { 3. Інших господарських стру- } \\
\text { ктур }\end{array}$ & 4,45 & 5,24 & 5,76 & 5,13 & 4,44 & 4,89 & 4,86 & 4,50 & 101,1 \\
\hline \multicolumn{9}{|c|}{ Структура надходжень, \% } & $(+,-)$ \\
\hline 1. СГП & 39,95 & 38,42 & 45,43 & 49,31 & 49,39 & 54,13 & 50,71 & 55,52 & $+15,6$ \\
\hline 2. Господарства населення & 2,88 & 0,81 & 0,40 & 0,66 & 0,77 & 0,20 & 3,40 & 4,53 & $+1,7$ \\
\hline $\begin{array}{l}\text { 3. Інші господарські структу- } \\
\text { ри }\end{array}$ & 57,18 & 60,77 & 54,18 & 50,02 & 49,84 & 45,68 & 45,89 & 39,95 & $-17,2$ \\
\hline
\end{tabular}

*Розраховано за даними Державної служби статистики України [11, 12]

Сьогодні багато українських учених-аграрників доводять необхідність створення зернових кооперативів в Україні. Так, С.М. Кваша наголошує на необхідності «соціалізації аграрного бізнесу способом державної підтримки стимулювання кооперативного розвитку середніх і малих форм господарювання» [6, с. 15]. М.Й. Хорунжий, підкреслюючи масштабність розвитку аграрного посередництва в Україні, наголошує на тому, що «держава зовсім дистанціювала від цієї проблеми». «Без державної допомоги, без кооперативного об'єднання, особистим селянським господарствам не вижити, вони й надалі згортатимуть свою діяльність, що неодмінно позначиться на загальному розвитку не лише аграрної, а також національної економіки», - пише вчений [9, с. 26]. М.Я. Дем'яненко розкриває іншу сторону цієї багатогранної проблеми. На його думку, концентрація коштів державної підтримки в економічно сильних господарствах протирічить завданню поновлення платоспроможності і створення рівних умов для усіх господарств аграрної системи. Основний ефект від їх застосування дістається часто не виробникам, а монополізованим структурам [5, с. 6].

Відповідно, створення та розвиток сільськогосподарських обслуговуючих кооперативів покликано розширити доступ малих і середніх суб'єктів аграрного сектору до різних форм державної підтримки. Такі кооперативи утворюються шляхом об'єднання фізичних та/або юридичних осіб - виробників сільськогосподарської продукції для організації обслуговування, спрямованого на зменшення витрат та/або збільшення доходів членів цього кооперативу під час провадження ними сільськогосподарської діяльності та на захист їхніх економічних інтересів (ст. 1 Закону України «Про сільськогосподарську кооперацію» №469-97-ВР [13]). Залежно від виду діяльності сільськогосподарські обслуговуючі кооперативи поділяються на переробні, заготівельно-збутові, постачаль- ницькі та інші. У разі поєднання кількох видів діяльності утворюються багатофункціональні кооперативи (ст. 5 Закону [13]).

У країнах із розвиненим сільським господарством основною й ефективною формою організації просування продукції $є$ кооперація й менш ефективною - агрохолдинги. У цих країнах близько 2/3 проданого зерна переробляють і реалізують через кооперативно-асоціативні об'єднання виробників і переробників. Так, у Франції функціонує більше 750 кооперативів, що охоплюють три чверті зернового ринку й володіють трьома чвертями потужностей зерносховищ. На французькі кооперативи припадає близько $70 \%$ збуту зернових культур [14]. У Німеччині кооперативи переробляють і реалізують близько 55 \% зерна; у Канаді функціонує понад 500 кооперативів з маркетингу й переробки зернових і олійних культур, членами яких є більше двох третин фермерів [15].

У 2013 р. в Україні діяло 562 сільськогосподарських обслуговуючих кооперативів, 3 них 26 (4,6 \%) - зернових, 181 (32,2\%) - молочарських, 120 $(21,4 \%)$ - 3 обробітку та збирання врожаю [10, с. 10 11]. Основними проблемами, що стримують розвиток сільськогосподарських обслуговуючих кооперативів, в т.ч. і зернових, в Україні, є такі [8, 10, 14]:

1. Недосконале законодавче забезпечення. Кооперативне законодавство потребує оновлення в напрямі взаємоузгодження Законів України «Про кооперацію», «Про сільськогосподарську кооперацію», «Про споживчу кооперацію», а також узгодження їх норм $з$ положеннями чинних Цивільного та Господарського кодексів України.

2. Недосконала система оподаткування, яка не відрізняє кооперативи від інших форм господарювання. Податкове законодавство не регламентує специфіки оподаткування кооперативів, зокрема звільнення від податку на прибуток кооперативних ви- 
плат. Це спричиняє невідповідність податкового статусу природі та принципам обслуговуючих кооперативів.

3. Недостатня державна підтримка створення нових та розвитку діючих кооперативів. У 2010 р. обсяг державної підтримки сільськогосподарських обслуговуючих кооперативів (КПКВК 2801150) склав 10,5 млн. грн., у 2011 р. він зменшився вдвічі (5 млн. грн), у 2012-2013 рр. видатки за даною програмною класифікацією не були закладені до бюджету [16, c. 251].

4. Неузгодженість економічних інтересів учасників кооперації, відсутність загального розуміння необхідності їхнього розвитку, нестача професійного менеджменту в діяльності об'єднань тощо.

Метою створення зернових обслуговуючих кооперативів в Україні є підвищення ефективності та оптимізація каналів просування зернових культур, вироблених малими і середніми СГП (юридичними особами) та господарствами населення (фізичними особами), на внутрішній і зовнішній ринки. Головними завданнями таких кооперативів $є$ підвищення доходності первинних виробників зерна, забезпечення для них доступності державної підтримки, узгодження попиту і пропозиції зерна із заданими параметрами якості, підвищення якості культур шляхом їх доробки та зберігання на кооперативному елеваторі (рис. 1).

Триєдність очікуваних ефектів включає економічний, соціальний і екологічний ефекти від створення та функціонування системи зернових кооперативів в Україні. Економічний ефект досягається шляхом переорієнтації товаропотоків зерна із непрозорих «інших каналів» в організовані кооперативні мережі, зростання доданої вартості, створеної в процесі зберігання та реалізації зерна, подолання інформаційної асиметричності зернового ринку. Екологічний ефект передбачає підвищення ефективності землекористування, родючості грунтів, виробництво екологічно чистої продукції відповідно до потреб внутрішніх і зовнішніх споживачів, сочіальний ефект - забезпечення зайнятості сільського населення, продовольчої безпеки держави (див. рис. 1).

META -

підвищення ефективності та оптимізація каналів просування зернових культур, вироблених малими і середніми сільськогосподарськими підприємствами (юридичними особами) та господарствами населення (фізичними особами), на внутрішній і зовнішній ринки

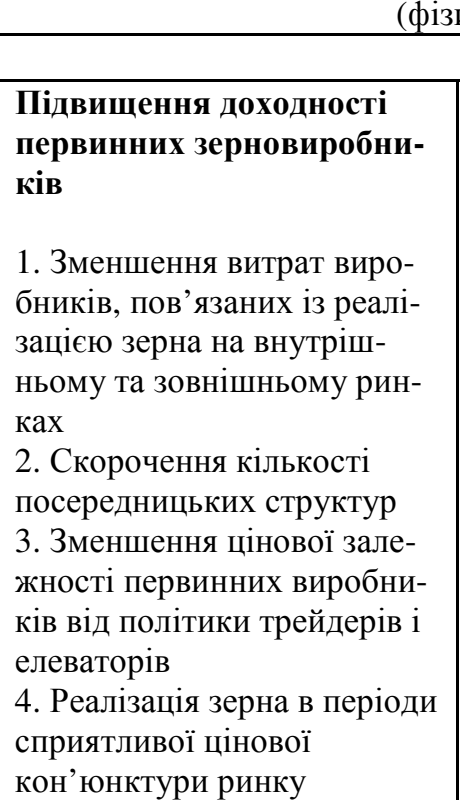

кон'юнктури ринку

\section{ЗАВДАННЯ}

Підвищення якості зерно-

\section{Соціальний}

1. Забезпечення зайнятості сільського населення.

2. Забезпечення продовольчої безпеки держави, узго-

дження попиту і пропозиції культур, що мають загально національне значення (зокрема, пшениці твердих сортів, пивоварного ячменю). вих культур

1. Об'єктивне визначення якісних параметрів зерна лабораторією кооперативного елеватору

2. Висока якість зернозберігаючих послуг за собівартісТю

3. Підвищення якості культур шляхом їх доробки та зберігання на кооперативному елеваторі

4. Формування однорідних за якісними показниками великих товарних зернових партій для їх подальшої реалізації

\section{ОЧІКУВАНІ ЕФЕКТИ

ОЧКУВАНГ ЕФЕКТИ
первинних виробників, узгодження попиту і пропозиції зерна із заданими параметрами якості

1. Пріоритетна участь зернового кооперативу в державних програмах розвитку зернового ринку

2. Налагодження прямих довгострокових зв'язків із зернопереробними підприємствами (за участю Аграрного фонду)

3. Координація та взаємоузгодження виробничих програм і планів вирощування продукції членами кооперативу у відповідності до внутрішніх потреб зернопереробних підприємств і держави.

4. Інформаційно-консультаційне забезпечення виробничої та збутової діяльності членів кооперативу.

1. Підвищення ефективності землекористування, родючості грунтів.

2. Виробництво високоякісної екологічно чистої та безпечної продукції для задоволення внутрішніх і зовнішніх потреб споживачів.

\section{Економічний}

1. Переорієнтація зернопотоків із непрозорих «інших каналів» в організовані збутові мережі (кооперативні, державні, зернопереробні)

2. Зростання доданої вартості, створеної в процесі зберігання та реалізації зерна

3. Подолання інформаційної асиметричності зернового ринку

4. Розширене відтворення ресурсів в аграрному секторі інтегрованого ринку

Рис. 1. Мета і завдання створення зернових обслуговуючих кооперативів в Україні [авторська розробка] 
Центральною ланкою регіонального обслуговуючого кооперативу постають районні та міжрайонні кооперативні елеватори (рис. 2). На думку В.О. Солопова, кооперативні елеватори $\epsilon$ «істинно ринковою формою інтеграції» [2, с. 136]. У даній площині позитивним є досвід США. Там всі елеватори у міру збільшення потужності діляться на сільські, субтермінальні та термінальні; сільські, в свою чергу, поділяються на «незалежні» (належать індивідуальному власнику), кооперативні і лінійні. Кооперативні елеватори знаходяться у власності фермерів певного регіону і управляються ними на кооперативних засадах. При цьому в одних регіонах переважають кооперативні елеватори, в інших - лінійні [2, с. 136]. Багатоманітність видів елеваторів в умовах конкурентного ринку забезпечує високий рівень послуг за оптимальної тарифної політики підприємств.

В Україні домінують лінійні елеватори; деякі 3 них, займаючи монопольне положення в регіоні, реалізують дискримінаційну тарифну політику відносно первинних виробників зерна. Відповідно, поява та розвиток такої форми інтеграції як кооперативні елеватори покликана вирішити низку системних взаємопов'язаних завдань створення ефективних кооперативних структур на зерновому ринку України (див. рис. 2).

Однією з умов ефективної діяльності районних і міжрайонних кооперативних елеваторів $\epsilon$ їх максимально повне завантаження зерновими культурами одного виду з подібними якісними показниками. Кооперативний елеватор, потужність якого в декілька разів менше потужностей лінійного елеватора, не зможе одночасно здійснювати доробку та зберігання багатьох різних культур або однієї культури з різними якісними показниками. Велика вартість зернових силосів визначає доцільність обмеження видів зернових культур для зберігання. Відповідно, забезпечення ефективності діяльності кооперативних елеваторів обумовлює необхідність координації та взаємоузгодження виробничих програм і планів вирощування продукції його членів (див. рис. 2).

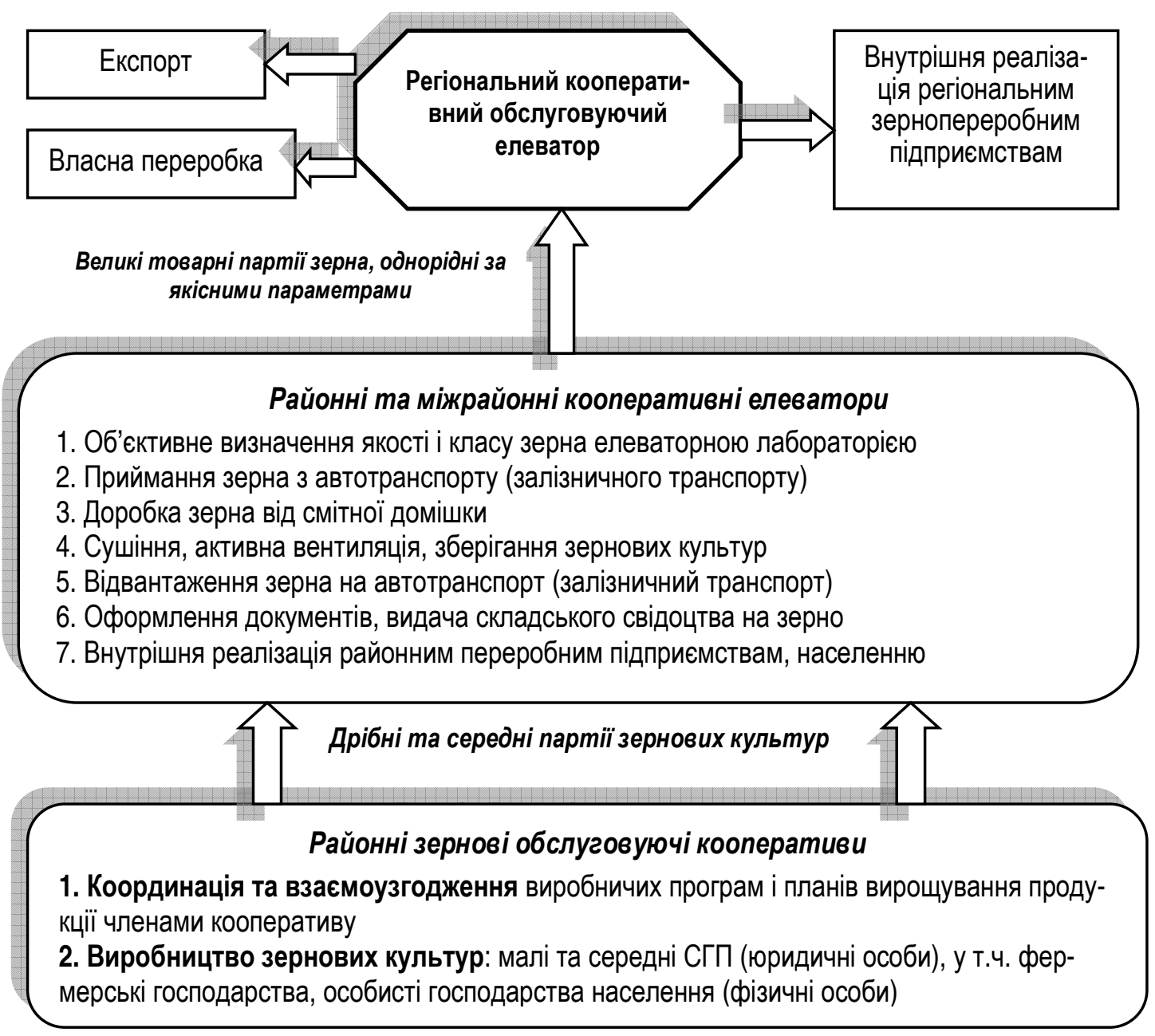

Рис. 2. Функціональна схема регіонального зернового обслуговуючого кооперативу

*Розроблено автором із використанням джерела [8, с. 139].

3 іншого боку, кооперативні елеватори можуть стати головними учасниками державних про- грам щодо стимулювання виробництва зернових культур із заданими параметрами якості, зокрема 
пшениці твердих сортів, високобілкових зернобобових культур [16, с. 295]. Пріоритетне включення мережі регіональних кооперативних елеваторів до участі в таких програмах може стати дієвою формою державної підтримки розвитку обслуговуючої кооперації і первинних зерновиробників в Україні, сприяючи генерації економічного, соціального та екологічного ефектів (див. рис. 1).

Згідно функціональної схеми, наведеної на рис. 2 , члени районних обслуговуючих кооперативів вироблене за попередньо узгодженою виробничою програмою зерно будуть здавати на районні та міжрайонні кооперативні елеватори відразу після його збирання за типом «поле - елеватор». На кооперативних елеваторах дрібні та середні партії зернових культур, що надходять від СГП та господарств населення, підлягатимуть об'єктивній оцінці власною лабораторією, доробці, зберіганню, відвантаженню та реалізації на локальних районних ринках або передачі на елеватор регіонального рівня. На регіональному кооперативному елеваторі відбуватиметься формування великих товарних партій зерна, однорідних за якісними показниками, для їх подальшої переробки, внутрішньої або експортної реалізації.

Ефективність функціонування кооперативних структур на зерновому ринку України визначимо шляхом порівняльного аналізу рівнів рентабельності та прибутку від реалізації зерна за посередницьким та кооперативним збутовими каналами у розрізі трьох сценарних варіантів: (1) реалізація на внутрішньому ринку; (2) надання зернозберігаючих послуг;
(3) реалізація зерна на зовнішньому ринку. Результати проведених автором розрахунків у даному напрямі узагальнено в таблиці 3.

У першому сценарному варіанті за умови реалізації зерна трейдеру «з поля» прибуток товаровиробника на 1 тонну пшениці складе 24,27 грн, iї рентабельність виробництва - усього 2,4\%. За умови шестимісячного зберігання зерна на кооперативному елеваторі і його внутрішньої реалізації в сприятливий ціновий період прибуток виробника досягне 591,38 грн/т, рентабельність продукції - 32,4 \%. Відповідно, можливість довгострокового зберігання зерна на кооперативному елеваторі дозволяє членам обслуговуючого кооперативу збільшити прибуток на 1 тонну пшениці у 24,4 рази та іiі рентабельність на $30 \%$ порівняно 3 аналогічними показниками, досягнутими при реалізації зерна за непрозорими «іншими каналами».

Специфічними витратами обслуговуючого кооперативу $\epsilon$ відрахування 3 прибутку на формування резервного фонду. Відповідно до ст. 2 Закону України «Про кооперацію» № 1087-IV від 10.07.2003 р. резервний фонд формується за рахунок відрахувань від доходу кооперативу та інших не заборонених законодавством надходжень i використовується для покриття збитків від надзвичайних ситуацій [18]. В ході розрахунків розмір відрахувань на формування резервного фонду кооперативу прийнято на рівні $10 \%$ (див. табл. 3).

Таблиця 3

Порівняльний аналіз рівнів рентабельності та прибутку від реалізації 1 т пшениці за посередницьким і кооперативним збутовим каналом*

\begin{tabular}{|c|c|c|}
\hline $\begin{array}{c}\text { Сценарії реалізації зерна за різними збутовими } \\
\text { каналами }\end{array}$ & $\begin{array}{c}\text { Реалізація за "іншими } \\
\text { каналами", грн./т }\end{array}$ & $\begin{array}{l}\text { Кооперативний збутовий } \\
\text { канал, грн./т }\end{array}$ \\
\hline І. Реалізація на внутрішньому ринку & "3 поля" & Через 6 міс. \\
\hline 1. Ціна пшениці, без ПДВ & 1035,42 & 2234,09 \\
\hline 2.Собівартість пшениці & 1011,15 & 1642,71 \\
\hline 3. Прибуток від реалізації (2-1) & 24,27 & 591,38 \\
\hline 4. Резервний фонд кооперативу (10\%) & - & 59,14 \\
\hline 5. Прибуток кооперативу (3-4) & 一 & 532,24 \\
\hline 6. Рентабельність, \% & 2,40 & 32,4 \\
\hline ІІ. Послуги з доробки та зберігання зерна & Приватний елеватор & Кооперативний елеватор \\
\hline 1. Вартість послуг елеватора (за 1 місяць) & 212,60 & 105,26 \\
\hline 1.1. Приймання з автотранспорту & 6,80 & 5,23 \\
\hline 1.2. Доробка зерна від смітної домішки & 10,50 & 5,70 \\
\hline 1.3. Сушіння зерна & 20,30 & 17,48 \\
\hline 1.4. Зберігання (за 1т / міс) & 15,70 & 11,88 \\
\hline 1.5. Відвантаження на автотранспорт & 34,30 & 19,48 \\
\hline $\begin{array}{l}\text { 1.6. Переоформлення документів з видачею } \\
\text { складських документів на зерно (1 партія) }\end{array}$ & 125,00 & 45,51 \\
\hline $\begin{array}{l}\text { 2. Собівартість пшениці, включаючи витрати на } \\
\text { зберігання зерна за } 6 \text { місяців }\end{array}$ & 2286,75 & 1642,71 \\
\hline 3. Прибуток (збиток) від реалізації & $-52,66$ & 591,38 \\
\hline 4. Резервний фонд кооперативу (10\%) & - & 59,14 \\
\hline
\end{tabular}




\begin{tabular}{|l|c|c|}
\hline 5. Прибуток кооперативу (3-4) & - & П32,24 \\
\hline 6. Рентабельність, \% & $\mathbf{- 2 , 3 0}, \mathbf{3 0}$ \\
\hline \multicolumn{1}{|l|}{ ІІ. Реалізація на зовнішньому ринку } & Портовий елеватор & $\begin{array}{c}\text { Припортовий коопера- } \\
\text { тивний елеватор }\end{array}$ \\
\hline 1.Транспортування зерна в порт (посередник) & 175,94 & 175,94 \\
\hline $\begin{array}{l}\text { 2. Послуги порту та оформлення документації } \\
\text { для експорту }\end{array}$ & 60,67 & 60,67 \\
\hline 3. Вартість послуг елеватору & 139,50 & 63,41 \\
\hline 4. Собівартість експортної реалізації зерна & 1599,86 & 1416,43 \\
\hline 5. Експортна ціна & 1948,00 & 1948,00 \\
\hline 6. Прибуток від експортної реалізації & 348,14 & 531,57 \\
\hline 7. Резервний фонд кооперативу (10\%) & - & 53,16 \\
\hline 8. Прибуток кооперативу (3-4) & - & 478,42 \\
\hline 9. Рентабельність, \% & $\mathbf{2 1 , 8}$ & $\mathbf{3 3 , 8}$ \\
\hline
\end{tabular}

*Розраховано автором за даними $[8,11,12,16,17]$.

Другий сценарний варіант ілюструє вартість зернозберігаючих послуг у розрізі їх складових на приватному та кооперативному елеваторах. Результати порівняльного аналізу свідчать, що вартість послуг кооперативного елеватора (105,26 грн./т ) вдвічі нижча тарифів приватного елеватора (212,6 грн./т). Як наслідок, собівартість пшениці, включаючи вартість їі доробки та зберігання на приватному елеватоpi за шість місяців, на 52,66 грн./т перевищує ціну реалізації, генеруючи від'ємну рентабельність продукції первинних зерновиробників - 2,3\%. Натомість зберігання пшениці на кооперативному елеваторі, що надає послуги свої членам за собівартістю, забезпечує рентабельності продукції на рівні $32,4 \%$.

Третій сценарний варіант відображає доходність експортної реалізації зерна за різними збутовими каналами. Вартість послуг припортового кооперативного елеватору $(63,41$ грн./т) на $55 \%$ менше тарифів портового елеватора, що за інших однакових витрат (транспортування зерна в порт, оформлення документів тощо) забезпечує вищу доходність експорту зерна за кооперативним збутовим каналом $(33,8 \%)$ порівняно 3 посередницьким $(21,8 \%)$ (див. табл. 3$)$. Проведені розрахунки доводять вищу ефективність функціонування кооперативного каналу порівняно 3 «іншими каналами» за усіма сценарними варіантами, обгрунтовуючи доцільність створення, розвитку та державної підтримки зернових обслуговуючих кооперативів.

Важливим стратегічним напрямом розвитку інфраструктури зернового ринку України повинно стати створення єдиного інформаиійного простору. Розвиток системи інформаційно-консультаційного забезпечення передбачає досягнення прозорості товарних, фінансових і інформаційних потоків між секторами інтегрованих ринків зерна і продуктів його переробки. Першим етапом становлення такої системи $€$ створювана в Україні мережа дорадчих служб, другим етапом може стати створення Аналітичної служби агросектору, головними завданнями якої будуть моніторинг базових параметрів розвитку стратегічних агропродовольчих ринків країни і поширення оперативної інформації серед суб’ єктів даних ринків [16, с 319-320].

В умовах обмежених бюджетних коштів основні функції Аналітичної служби доцільно покласти на відділ моніторингу аграрного ринку Департаменту економічного розвитку аграрного ринку Міністерства аграрної політики та продовольства України. Окрім системного моніторингу базових параметрів розвитку агропродовольчих ринків, доцільно розширити завдання і функції відділу в напрямах доведення оперативних аналітичних даних до малих і середніх СГП; розширення інформаційної бази за рахунок показників, використання яких дозволить підвищити прибутковість господарств первинних агровиробників, збільшити вірогідність прийняття ними правильних економічних рішень в умовах варіативної кон'юнктури товарних ринків. Також доцільно активізувати діяльність відділів розвитку сільськогосподарської кооперації та координації дорадництва Департаменту науково-освітнього забезпечення АПВ та розвитку сільських територій [19], розширити їх завдання в напрямі здійснення системного моніторингу діяльності кооперативів, у т.ч. і зернових, та дорадчих служб.

Створення та розвиток мережі зернових обслуговуючих кооперативів в Україні, а також системи дорадництва залежить, передусім, від обсягів бюджетного фінансування та цільового їх використання. Слід підкреслити, що заходи на розвиток інфраструктури аграрного ринку входять до складу «зеленої скриньки», відтак їх фінансування не обмежується правилами СОТ. Згідно 3 додатком 2 до Угоди про сільське господарство, державні витрати в межах «зе- 
леної скриньки» можуть здійснюватись, зокрема, у таких напрямах [20]: (1) послуги 3 розповсюдження інформації та консультативні послуги; (2) послуги 3 маркетингу i просування товару на ринок; (3) створення державних резервів для забезпечення продовольчої безпеки. На нашу думку, пріоритетне включення зернових кооперативів до участі у державних «зелених» програмах щодо створення продовольчих резервів сприятиме розвитку організованого кооперативного збутового каналу на зерновому ринку України.

Висновки та перспективи подальших досліджень. У ході дослідження автором ідентифіковано низку деформацій у розвитку збутової системи зернового ринку України, зокрема: (1) неузгодженість економічних інтересів суб'єктів виробництва, зберігання та експорту зерна; (2) залежність первинних зерновиробників від цінової політики трейдерів та регіональних приватних елеваторів; (3) перманентне зростання в структурі реалізації зерна частки непрозорих «інших каналів» за рахунок скорочення питомої ваги зернопереробного збутового каналу; (4) інформаційна асиметричність зернового ринку; (5) зниження кількісної і фінансової прозорості товарних потоків зерна і продуктів його переробки. Подолання перелічених деформацій знаходиться у площині створення системи зернових обслуговуючих кооперативів, ядром яких є районні і міжрайонні кооперативні елеватори. Проведений автором порівняльний аналіз рівнів рентабельності та прибутку від реалізації 1 тонни пшениці за посередницьким і кооперативним каналом наочно довів ефективність останнього, а саме: рентабельність реалізації зерна за відповідними збутовими каналами склала 2,4\% i
$32,4 \%$ у першому, $-2,3 \%$ i $32,4 \%$ у другому та $21,8 \%$ і $33,8 \%$ у третьому сценарному варіантах.

Формами державної підтримки створення та розвитку зернових кооперативів можуть бути їх пріоритетне включення до участі в державних програмах щодо стимулювання виробництва зернових культур із заданими параметрами якості (зокрема, пшениці твердих сортів, високобілкових зернобобових культур), бюджетних програмах щодо створення продовольчих резервів в межах заходів «зеленої скриньки». Стратегічне завдання створення єдиного інформаційного простору передбачає розширення функцій Департаменту економічного розвитку аграрного ринку в напрямі доведення оперативних аналітичних даних до малих i середніх СГП i Департаменту науковоосвітнього забезпечення АПВ в напрямі здійснення системного моніторингу діяльності зернових кооперативів і дорадчих служб.

Прикладне значення авторських розробок визначається можливістю їх використання державними органами влади в ході обгрунтування економічної доцільності створення, розвитку та підтримки системи зернових кооперативів в Україні, оцінки ефективності кооперативного збутового каналу порівняно 3 альтернативними напрямами реалізації зерна. Перспективи подальших досліджень полягають в ідентифікації передумов створення кооперативних об'єднань на стратегічних агропродовольчих ринках України, обгрунтування організаційної структури регіональних кооперативів, розрахунку ефективності функціонування кооперативного збутового каналу із використанням методичного підходу, висвітленого в даній статті.

\section{Література}

1. Алтухов А. И. Зерно России / А. И. Алтухов, А. С. Васютин. - М.: ЭКОНДС-К, 2002. - 432 с.

2. Солопов В. А. Развитие регионального рынка зерна и хлебопродуктов : науч. издание./ В. А. Солопов. - Мичуринск-наукоград РФ : Изд-во Мичурин. гос. аграр. ун-та, 2006. - 315 с.

3. Ambler T. (2008) “Assessing marketing performance: Don't settle for a silver metric”, Journal of Marketing Management, 24(7-8), 733-750.

4. Jobber D. (2001) "Principles and practice of marketing", 3 ed., 450 p.

5. Державна політика фінансової підтримки розвитку аграрного сектору АПК : монографія; за ред. М. Я. Дем’яненка. - К. : ННЦ Інститут аграрної економіки, 2011. - 372 с.

6. Кваша С. М. Методологічний базис прийняття суспільних рішень в аграрній політиці / С. М. Кваша // Економіка АПК. - 2013. - № 8. - С. 12-21.

7. Саблук П. Т. Реалізація механізму реформ в аграрній сфері / П. Т. Саблук // Економіка АПК. - 2011. - №10. - С.3-6.

8. Франченко Л. О. Оптимізація каналів просування виробниками зерна на світовий ринок / Л. О. Франченко // Економіка АПК. - 2013. - № 9. - С. 136-141. 
9. Хорунжий М. Й. Завдання національної аграрної політики на сучасному етапі / М. Й. Хорунжий // Економіка АПК. - 2014. - № 2. - С. 22-29.

10. Шебанін В. С. Розвиток кооперації в АПК: проблеми та напрями їі подолання / В. С. Шебанін // Економіка АПК. - 2013. - № 2. - С. 9-12.

11. Офіційний сайт Державної служби статистики України. Розділ «Економічна діяльність». [Електронний ресурс] - Режим доступу : //http://www.ukrstat.gov.ua/- 09.04.2015 p.

12. Статистичний щорічник України за 2013 рік / За ред. О. Г. Осауленка. - К.: ТОВ «Август Трейд», 2014. $-533 \mathrm{c}$.

13. Про сільськогосподарську кооперацію : Закон України №469-97-ВР від 17 липня 1997 р. [Електронний ресурс] - Режим доступу : http://zakon2.rada.gov.ua/laws/show/469/97 - 09.04.2015 p.

14. Bondarchuk V, Alkoley J. R. (2015) "Cooperation as a way life", available at: http://www.zerno.org.ua/articles/coop/279 (Accessed April 09, 2015).

15. "Revitalizing Canada's economy: cooperatives are part of the solution" (2015), available at: http://www.coopscanada.coop/assets/firefly/files/pdfs (Accessed April 09, 2015).

16. Нікішина О. В. Механізми регулювання інтегрованого зернового ринку / О. В. Нікішина. - Одеса: ІПРЕЕД НАН України, 2014. - 450 с.

17. Nikishina O. V. (2014) "Sectoral Analysis of Reproduction Processes at the Integrated Grain Market of Ukraine", Nauka i Studia, 1 (111), 105 - 111.

18. Про кооперацію : Закон України №1087-IV від 10 липня 2003 р. [Електронний ресурс] - Режим доступу : http://zakon4.rada.gov.ua/laws/show/1087-15 - 09.04.2015 p.

19. Положення про Департамент науково-освітнього забезпечення АПВ та розвитку сільських територій Міністерства аграрної політики та продовольства України : Наказ Міністерства аграрної політики № 789 від 19 грудня 2012 р. [Електронний ресурс] - Режим доступу : http://minagro.gov.ua/uk/ministry?nid=3047 09.04.2015.

20. У Угда про сільське господарство. Міжнародний документ № 981-005 від 15.04.1994 р. [Електронний pecyрс] - Режим доступу : http://zakon2.rada.gov.ua/laws/show/981_005. - 09.04.2015 p.

Стаття надійшла 20.04.2015

\author{
Никишина О.В. \\ кандидат экономических наук, докторант \\ отдел рыночных механизмов и структур \\ Институт проблем рынка и экономико-экологических исследований НАН Украины \\ Французский бульвар, 29, г. Одесса, Украина, 65044 \\ E-mail: ksenkych@gmail.com.
}

\title{
КООПЕРАТИВНЫЕ ОБЪЕДИНЕНИЯ В РАЗВИТИИ ИНФРАСТРУКТУРЫ ЗЕРНОВОГО РЫНКА УКРАИНЫ
}

Сбытовой системе зернового рынка Украины присущи такие деформации: (1) доминирование в структуре реализации зерна непрозрачных «других каналов» (86,8\% в 2013); (2) уменьшение доли зерна, реализованного перерабатывающим предприятиям с 80,4\% в 1990 г. до 4\% в 2013 г.; (3) зависимость первичных производителей зерна от ценовой политики трейдеров и региональных элеваторов; (4) снижение количественной, финансовой и информационной прозрачности товарных потоков зерна; (5) наличие посредников в зерновой торговле, рост себестоимости продуктов зернопереработки. Преодоление перечисленных деформаций обусловливает необходимость диверсификации существующих каналов сбыта за счет развития кооперативного канала реализации зерновых культур.

Иностранный опыт функционирования кооперативных объединений свидетельствует об их ведущей роли на зерновых рынках Франции, Германии и Канады. В Украине в 2013 действовало всего 26 зерновых кооперативов (4,6\% от общего количества сельскохозяйственных кооперативов). Главными 
причинами, сдерживающими развитие зерновых кооперативов, являются несовершенная система налогообложения и низкий уровень государственной поддержки.

Целью создания зерновых обслуживающих кооперативов в Украине является повышение эффективности и оптимизация каналов продвижения зерновых культур, производимых малыми и средними предприятиями (юридическими лицами) и хозяйствами населения (физическими лицами), на внутренний и внешний рынки. Функционирование системы зерновых кооперативов генерирует триединство ожидаемых эффектов. Экономический эффект достигается путем переориентации товаропотоков зерна с непрозрачных «других каналов» в организованные кооперативные сети, рост добавленной стоимости зерна, преодоление информационной асимметрии рынка. Экологический эффект предусматривает повышение эффективности землепользования и плодородия почв, социальный эффект - обеспечение занятости сельского населения, продовольственной безопасности государства.

Функционирование в составе регионального обслуживающего кооператива кооперативного элеватора призвано обеспечить доходность непосредственных зернопроизводителей. Проведенные автором расчеты показали высокую эффективность кооперативного канала реализации зерновых культур по сравнению с посредническим каналом.

Формами государственной поддержки кооперативных объединений могут быть приоритетное включение зерновых кооперативов в участие в программах по стимулированию производства зерновых культур с заданными параметрами качества, «зеленых» программах по созданию продовольственных резервов.

Ключевые слова: зерновой кооператив, инфраструктура рынка, сбытовые каналы, кооперативный элеватор, эфффективность реализации зерна.

\author{
Nikishina O.V. \\ Ph.D. in Economics, Doctoral candidate \\ Department of market mechanisms and structures \\ Institute of market problems and economic \& ecological research \\ of National Academy of Sciences of Ukraine \\ Frantsuzskiy boulevard, 29, Odessa, Ukraine, 65044 \\ E-mail: ksenkych@gmail.com.
}

\title{
COOPERATIVE ASSOCIATIONS IN DEVELOPMENT OF INFRASTRUCTURE THE GRAIN MARKET UKRAINE
}

Marketing system the grain market of Ukraine has such deformations: (1) dominance in structure of grain sales the opaque «other channels» $(86,8 \%$ in 2013$)$; (2) reducing share of grain, sold to processing enterprises, with $80,4 \%$ in 1990 to $4 \%$ in 2013; (3) dependence of direct producers grain from pricing policy traders and regional elevators; (4) reducing quantitative, financial and information transparency of grain trade flows; (5) presence of intermediaries in grain trade, increase cost of grain processing products. Overcoming these deformations stipulates the necessity diversify existing sales channels, developing cooperative channel of realization grain crops.

Foreign experience of functioning cooperative associations demonstrates their leading role in grain markets of France, Germany and Canada. In Ukraine, in 2013 there were a total of 26 grain cooperatives (4,6\% all agricultural cooperatives). Main reasons that hinder the development of grain cooperatives, are imperfect system of taxation and low level of state support.

Purpose of grain service cooperatives in Ukraine is to increase efficiency and optimization of sales channels grain crops, produced by small and medium-sized enterprises (legal entities) and farms of the population (individuals) in internal and external markets. Functioning system grain cooperatives generates of trinity expected effects. Economic effect is achieved by a reorientation of trade flows grain with opaque «other channels» in organized cooperative network, growth of value added the grain, overcome of information asymmetry 
market. Environmental effect involves improving the efficiency of land use and soil fertility, social effect - provision of rural employment, state food security.

Functioning as part of a regional service cooperative the cooperative elevator aims to provide profitability of direct producers grain. Conducted author calculations have proved higher efficiency of cooperative channel of realization grain crops relative with intermediary channel.

Forms of state support cooperative associations may be priority inclusion of grain cooperatives to participate in programs to stimulate the production of of grain crops with desired quality parameters, "green» programs for creating food reserves.

Keywords: grain cooperative, infrastructure market, sales channels, cooperative elevator, efficiency of realization grain.

\section{References}

1. Altuhov A. I., Vasyutin A. S (2002). Zerno Rossii, M.: EKONDS-K, 432.

2. Solopov V. A. (2006). Razvitie regionalnogo ryinka zerna i hleboproduktov, Michurinsk-naukograd RF: Izd-vo Michurin. gos. agrar. un-ta, 315.

3. Ambler T. (2008). Assessing marketing performance: Don't settle for a silver metric, Journal of Marketing Management, 24(7-8), 733-750.

4. Jobber D. (2001). Principles and practice of marketing, 3 ed., 450.

5. Derzhavna polityka finansovoi pidtrymky rozvytku ahrarnoho sektoru APK: monohrafiia (2011), za red. M. Ya. Demianenka, K.: NNTs Instytut ahrarnoi ekonomiky, 372.

6. Kvasha S. M. (2013). Metodolohichnyi bazys pryiniattia suspilnykh rishen v ahrarnii politytsi, Ekonomika $A P K, 8,12-21$.

7. Sabluk P. T. (2011). Realizatsiia mekhanizmu reform v ahrarnii sferi, Ekonomika APK, 10, 3-6.

8. Franchenko L. O. (2013). Optymizatsiia kanaliv prosuvannia vyrobnykamy zerna na svitovyi rynok, Ekonomika APK, 9, 136-141.

9. Khorunzhyi M. Y. (2014). Zavdannia natsionalnoi ahrarnoi polityky na suchasnomu etapi, Ekonomika APK, 2, 22-29.

10. Shebanin V.S. (2013). Rozvytok kooperatsii v APK: problemy ta napriamy yii podolannia, Ekonomika $A P K, 2,9-12$.

11. Ofitsiinyi sait Derzhavnoi sluzhby statystyky Ukrainy (2015). Rozdil "Ekonomichna diialnist". [Elektronnyi resurs] - Rezhym dostupu: //http://www.ukrstat.gov.ua/ (09.04.2015).

12. Statystychnyi shchorichnyk Ukrainy za 2013 rik (2014), za red. O. H. Osaulenka, K.: TOV «Avhust Treid», 533.

13. Pro silskohospodarsku kooperatsiiu: Zakon Ukrainy № 469-97-VR vid 17 lypnia 1997 r. [Elektronnyi resurs] - Rezhym dostupu: http://zakon2.rada.gov.ua/laws/show/469/97 (09.04.2015).

14. Bondarchuk V, Alkoley J. R. (2015). Cooperation as a way life, available at: http://www.zerno.org.ua/articles/coop/279 (Accessed April 09, 2015)

15. Revitalizing Canada's economy: cooperatives are part of the solution (2015), available at: http://www.coopscanada.coop/assets/firefly/files/pdfs (Accessed April 09, 2015)

16. Nikishyna O. V. (2014). Mekhanizmy rehuliuvannia intehrovanoho zernovoho rynku, Odesa: IPREED NAN Ukrainy, 450.

17. Nikishina O. V. (2014). Sectoral Analysis of Reproduction Processes at the Integrated Grain Market of Ukraine, Nauka i Studia, 1 (111), 105 - 111.

18. Pro kooperatsiiu: Zakon Ukrainy № 1087-IV vid 10 lypnia 2003 r. [Elektronnyi resurs] - Rezhym dostupu: http://zakon4.rada.gov.ua/laws/show/1087-15 (09.04.2015).

19. Polozhennia pro Departament naukovo-osvitnoho zabezpechennia APV ta rozvytku silskykh terytorii Ministerstva ahrarnoi polityky ta prodovolstva Ukrainy: Nakaz Ministerstva ahrarnoi polityky № 789 vid 19 hrudnia 2012 r. [Elektronnyi resurs] - Rezhym dostupu: http://minagro.gov.ua/uk/ministry?nid=3047 (09.04.2015).

20. Uhoda pro silske hospodarstvo. Mizhnarodnyi dokument № 981-005 vid 15.04.1994 r. [Elektronnyi resurs] - Rezhym dostupu: http://zakon2.rada.gov.ua/laws/show/981_005 (09.04.2015). 